\title{
IT SOLUTION FOR DISEASE MANAGEMENT AT PT PANASONIC MANUFACTURING INDONESIA
}

\author{
Bens Pardamean; Anjela Greizaria Djoeang; Nana Rosanna Br. L. Tobing \\ Program Magister Teknik Informatika, Fakultas Ilmu Komputer, BINUS UNIVERSITY \\ Jln. Kebon Jeruk Raya No. 27, Jakarta 11530 \\ dr.bens@binus.ac.id
}

\begin{abstract}
One of company's occupational health programs is disease management which is a part of preventive health care. In its realization, it was discovered that there some challenges in data collection, monitoring of catering and sport activity, employee health reports, and medical costs. The purpose of this study is to design an IT solution for the disease management program at PT. Panasonic Manufacturing Indonesia (PMI). The diseases in focus are diabetes, hypertension, and tuberculosis. Methodology starts with survey on PT. PMI requirements, research parameters, problem analysis, literature study, and system design. Solution is focused on designing a registry system that includes Alert Management System, Food Tracking, EHR, Sport Tracking, Guidelines, and Report System. The results of this study is a web-based information system that can assist health care workers in seeking data, monitoring food intake and sport activity, and reporting systems for upper-level management.
\end{abstract}

Keywords: health care, IT solution, disease management, registry system

\begin{abstract}
ABSTRAK
Salah satu program kesehatan kerja sebuah perusahaan adalah disease management yang merupakan bagian dari preventive health care. Dalam pelaksanaannya terdapat kesulitan dalam mencari data, memantau makanan dan aktifitas olahraga, pembuatan laporan kesehatan karyawan, dan biaya pengobatan. Studi ini bertujuan merancang solusi teknologi informasi pada program disease management PT. Panasonic Manufacturing Indonesia (PMI). Cakupan penyakit pada studi ini adalah diabetes, hipertensi, dan tuberculosis. Studi dimulai dari survei terhadap kebutuhan PT. PMI, mencari parameter ketiga penyakit tersebut, analisis masalah, studi literatur, dan perancangan sistem. Solusi difokuskan pada perancangan sistem registry yaitu Alert Management System, Food Tracking, EHR, Sport Tracking, Guidelines dan Report System. Hasil studi ini adalah sistem informasi berbasis web yang dapat memudahkan petugas kesehatan kerja dalam mencari data, memantau makanan dan aktifitas olahraga karyawan; serta sistem pelaporan untuk top management.
\end{abstract}

Kata kunci: health care, solusi TI, manajemen penyakit, system registry 


\section{PENDAHULUAN}

Departemen Kesehatan Kerja di PT Panasonic Manufacturing Indonesia memiliki program pencegahan (prevention), klinik (clinic), dan pengobatan (treatment). Disease management merupakan bagian dari medical treatment untuk menangani karyawan yang menderita penyakit kronis. Seseorang dikatakan menderita penyakit kronis apabila menderita penyakit dalam kurun waktu lebih dari tiga bulan atau seumur hidup.

Disease management merupakan bentuk praktik kesehatan yang merawat pasien berisiko dan berbiaya tinggi. Disease management juga memiliki banyak variasi dalam pengobatannya. Program ini merupakan strategi pengobatan dan cara untuk memelihara kesehatan pasien penyakit kronis.

Program petunjuk penanganan dasar pada pasien (evidence-based disease management) dirancang untuk membantu pasien agar dapat merawat dirinya sendiri dan menyediakan informasi klinik bagi dokter dan tim perawat (Bowles, Holland, \& Horowitz, 2009). Disease management memiliki pedoman dalam pelaksanaannya. Pedoman tersebut dibuat berdasarkan hasil pemeriksaan kondisi terakhir pasien yang bisa diketahui dari hasil screening, penilaian, pemantauan, dan pengobatan terhadap pasien (Bowles, Pham, \& O’Connor, 2010).

Salah satu bentuk disease management adalah Chronic Care Model (CCM) yang dikembangkan oleh Wagner, dkk (1999) dan digunakan sebagai kerangka kerja konseptual untuk merawat pasien yang menderita penyakit kronis (Beich, Scanlon, Ulbrecht, Ford, \& Ibrahim, 2006; Bodenheimer, Wagner, Grumbach, 2002; Frei et al., 2010; Langford, Sawyer, Gioimo, Brownson, \& O’Toole, 2007; Nutting et al., 2007; Strickland et al., 2010; Zai et al., 2008). CCM bertujuan untuk mengintegrasikan konsep berdasarkan petunjuk (evidence-based concepts) yang ada kedalam kerangka kerja konseptual (Frei et al., 2010).

CCM terdiri dari enam komponen perawatan yaitu: mendukung penanganan diri (selfmanagement), mendukung keputusan, desain sistem pengantaran, sistem informasi klinis, organisasi kesehatan, dan sumber daya komunitas (Bodenheimer et al., 2002; Frei et al., 2010; Langford et al., 2007; Strickland et al., 2010; Zai et al., 2008).

Penyakit kronis dalam studi ini difokuskan pada diabetes, hipertensi dan tuberculosis (TBC). Diabetes adalah penyakit dimana tubuh gagal memproduksi insulin atau tidak bisa memanfaatkan insulin sehingga tidak dapat menguraikan gula dan sari makanan (Beaulieu, Cutler, Ho, Horrigan, \& Isham, 2003). Hal ini yang menyebabkan tingginya glukosa darah atau kadar gula dalam darah. Insulin adalah hormon yang dibuat didalam pankreas, yang membantu menguraikan sari makanan menjadi energi.

Kadar gula sebelum makan terbagi atas lima kategori yaitu terkategori normal, diabetes, abnormal glucose tolerance, abnormal fasting blood sugar, dan low blood sugar serta kadar gula setelah makan dapat dikategorikan normal, diabetes, abnormal glucose tolerance, dan abnormal fasting blood sugar (Kim, Lee, Yoon, \& Gaton, 2007). Untuk mendeteksi penyakit diabetes dapat dilakukan pemeriksaan HbA1C. Nilai HbA1C bagi mereka yang bukan penderita diabetes adalah sekitar 3.5-5.5\%. Sedangkan bagi penderita diabetes, kadar HbA1C dikatakan cukup baik jika bernilai 6.5\%. Menurut American Diabetes Association (ADA), kadar HbA1C diatas 6.5\% didiagnosis terkena diabetes. Diantara 5.7-6.4\% diduga pre-diabetes atau memiliki risiko terkena diabetes. Kurang dari $5.6 \%$ dianggap bebas dari diabetes. Nilai A1C merupakan indikator terpenting untuk mengetahui kondisi diabetes dan akan menjadi parameter dalam diabetes disease management. Pasien diharapkan bisa mengendalikan diabetes mereka secara mandiri agar terhindar dari penyakit komplikasi akibat diabetes sehingga bisa menekan biaya untuk berobat. Panduan pada penyakit diabetes memerlukan 
ketersediaan tes hemoglobin glycosolated terbaru atau HbA1C, laporan gula darah sebelum dan setelah makan, dokumentasi kemampuan pasien dalam mengenali hypoglycemia, kadar kolesterol dan trigliserida, pemeriksaan mata tahunan, dan pengukuran tekanan darah, dan juga rejimen pengobatan untuk menangani diabetes (Bowles et al., 2010).

Hipertensi atau yang lebih sering dikenal dengan tekanan darah tinggi terjadi pada arteri jantung. Tekanan darah adalah pengukuran terhadap dinding arteri saat jantung memompa darah ke seluruh tubuh (US National Library of Medicine [NLM], 2010). Tekanan darah diukur dengan menggunakan dua buah angka yang mereprensentasikan sistol dan diastol. Tekanan darah manusia pada umumnya adalah 120/80 mmHg. Angka 120 merepresentasikan tekanan sistol dimana tekanan yang terjadi selama jantung berdetak. Sedangkan angka 80 merepresentasikan tekanan diastol dimana tekanan yang terjadi ketika jantung beristirahat berdetak. Alat pengukur tekanan darah disebut sphygmomanometer. Hasil pengukuran tekanan sistol dan diastol ini yang akan menjadi input parameter dalam sistem hipertensi disease management.

Tekanan darah diklasifikasikan sebagai berikut:

1. Tekanan darah normal adalah kondisi dimana nilai sistol kurang dari $120 \mathrm{mmHg}$ dan diastol kurang dari $80 \mathrm{mmHg}$.

2. Prehipertensi adalah kondisi dimana nilai sistol berada di antara 120 - $139 \mathrm{mmHg}$ atau diastol 80 $89 \mathrm{mmHg}$.

3. Hipertensi tahap 1 adalah kondisi dimana nilai sistol berada di antara 140 - $159 \mathrm{mmHg}$ atau diastol 90 - $99 \mathrm{mmHg}$

4. Hipertensi tahap 2 adalah kondisi dimana nilai sistol diatas $160 \mathrm{mmHg}$ atau diastol diatas 100 mmHg.

Pada penyakit TBC, dikenal istilah Pengobatan LTBI (Latent Tuberculosis Infection) yang digunakan untuk mencegah penyebaran penyakit TBC dan digunakan bersama obat-obatan. Pengujian target ini digunakan untuk mengidentifikasi dan mengobati pasien yang memenuhi kriteria sebagai berikut: (1) Beresiko tinggi untuk terinfeksi M. tuberculosis; dan (2) Beresiko tinggi terkena penyakit TB sekali terinfeksi dengan $M$. tuberculosis. Pasien dalam kelompok ini seharusnya menerima prioritas pertama untuk pengobatan LTBI jika hasil Tuberculin Skin Test (TST) mereka dinyatakan positif atau Interferon-Gamma Release Assay (IGRA).

Rejimen pengobatan TB (Tabel 1) terdiri dari empat jenis obat yaitu: Isoniazid (INH), Rifampin (RIF), Pyrazinamide (PZA), dan Ethambutol (EMB). Setiap obat dilengkapi dengan lama pengobatan dan dosis yang digunakan. Pedoman perawatan dan pengobatan penyakit TBC pada studi ini bersumber dari dari pedoman yang dikeluarkan Centers for Disease Control and Prevention (CDC, 2010).

Tabel 1 Rejimen Pengobatan TBC dan Dosis yang Disarankan

\begin{tabular}{|c|c|c|c|c|c|c|}
\hline \multicolumn{3}{|c|}{ Fase Awal } & \multicolumn{4}{|c|}{ Fase Berikutnya } \\
\hline Rejimen & Obat & $\begin{array}{l}\text { Waktu \& } \\
\text { Dosis } \pm\end{array}$ & Rejimen & Obat & $\begin{array}{l}\text { Waktu \& } \\
\text { Dosis } \pm \S\end{array}$ & $\begin{array}{l}\text { Kisaran } \\
\text { Total Dosis }\end{array}$ \\
\hline 1 & $\begin{array}{l}\text { INH } \\
\text { RIF } \\
\text { PZA } \\
\text { EMB }\end{array}$ & $\begin{array}{l}7 \text { hari / } \\
\text { minggu } \\
\text { untuk } 56 \\
\text { dosis } \\
\text { (56 } \\
\text { minggu) } \\
\text { atau } \\
5 \text { hari / }\end{array}$ & $1 \mathrm{a}$ & $\begin{array}{l}\text { INH } \\
\text { RIF }\end{array}$ & $\begin{array}{l}7 \text { hari / } \\
\text { minggu } \\
\text { untuk } 126 \\
\text { dosis atau } \\
5 \text { hari / } \\
\text { minggu } \\
\text { untuk } 90 \\
\text { dosis }\end{array}$ & $\begin{array}{l}182 \text { - } 130 \\
\text { (26 minggu) }\end{array}$ \\
\hline
\end{tabular}




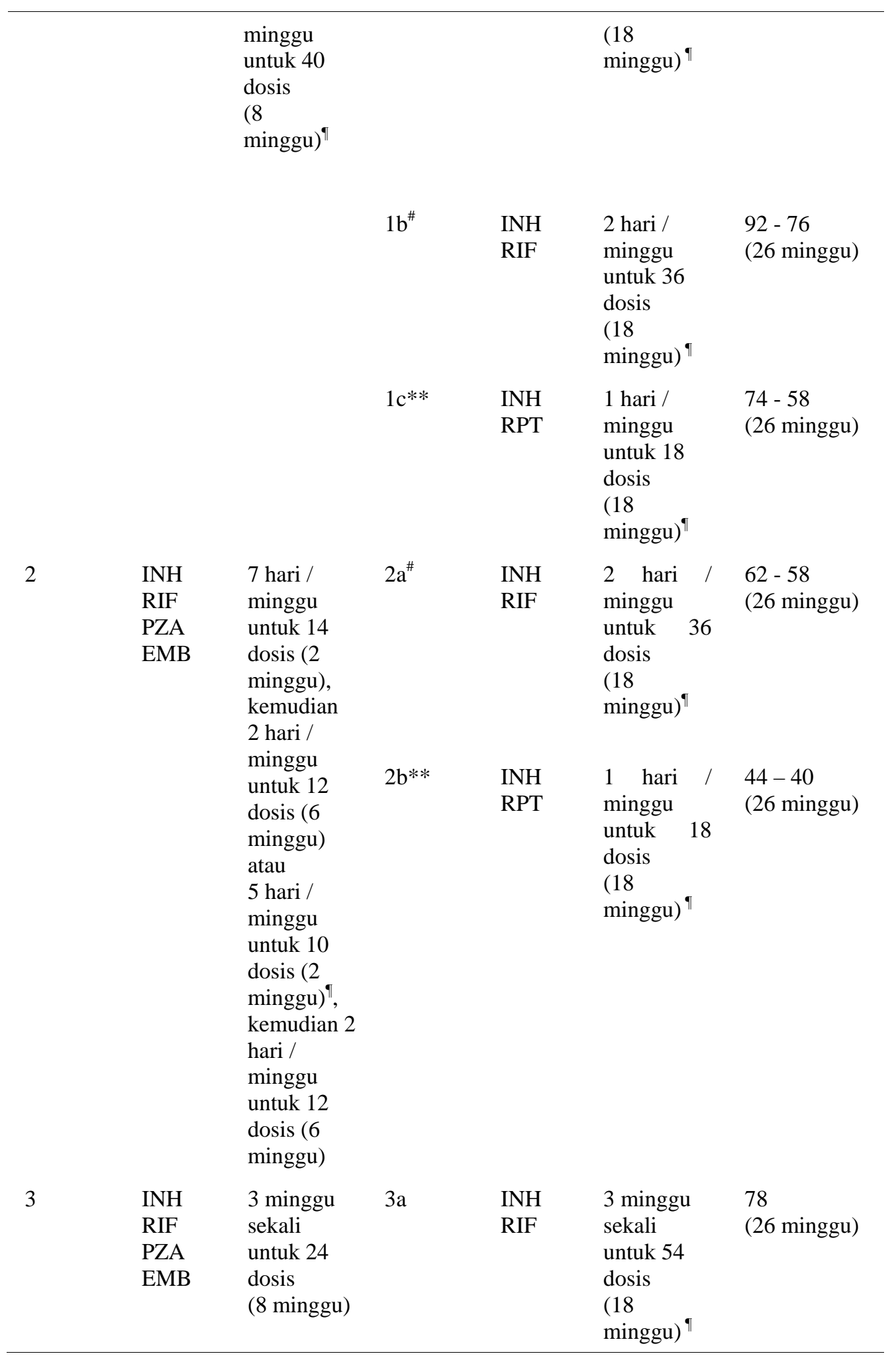




\begin{tabular}{|c|c|c|c|c|c|c|}
\hline \multirow[t]{2}{*}{4} & $\begin{array}{l}\text { INH } \\
\text { RIF } \\
\text { EMB }\end{array}$ & $\begin{array}{l}7 \text { hari / } \\
\text { minggu } \\
\text { untuk } 56 \\
\text { dosis (8 } \\
\text { minggu) } \\
\text { atau } \\
5 \text { hari / } \\
\text { minggu } \\
\text { untuk } 40 \\
\text { dosis (8 } \\
\text { minggu) }\end{array}$ & $4 a$ & $\begin{array}{l}\text { INH } \\
\text { RIF }\end{array}$ & $\begin{array}{l}7 \text { hari / } \\
\text { minggu } \\
\text { untuk } 217 \\
\text { dosis (31 } \\
\text { minggu) } \\
\text { atau } \\
5 \text { hari / } \\
\text { minggu } \\
\text { untuk 155 } \\
\text { dosis (31 } \\
\text { minggu) }\end{array}$ & $\begin{array}{l}273 \text { - } 195 \\
\text { (39 minggu) }\end{array}$ \\
\hline & & & $4 b^{\#}$ & $\begin{array}{l}\text { INH } \\
\text { RIF }\end{array}$ & $\begin{array}{l}\text { Dua kali } \\
\text { seminggu } \\
\text { untuk } 62 \\
\text { dosis (31 } \\
\text { minggu) }\end{array}$ & $\begin{array}{l}118 \text { - } 102 \\
\text { (39 minggu) }\end{array}$ \\
\hline
\end{tabular}

\section{Keterangan simbol pada tabel 1:}

1. Simbol $(*)$ berarti untuk informasi lebih lanjut mengenai kekuatan saran dan kualitas untuk mendukung bukti, lihat ATS, CDC (CDC, 2010), dan IDSA MMWR pada panduan pengobatan TB.

2. Simbol ( \pm ) berarti ketika DOT digunakan, obat-obatan diberikan 5 hari / minggu dan disesuaikan dengan dosis yang diperlukan.

3. Simbol (§) berarti pasien yang memiliki rongga pada awal pemeriksaan X-Ray dada dan budaya positif yang diselesaikan dalam dua bulan terapi seharusnya menerima fase lanjutan selama tujuh bulan.

4. Simbol (ף) Pasien yang diberikan rejimen kurang dari 7 hari seminggu harus menerima DOT.

5. Simbol (\#) berarti rejimen berlangsung kurang dari tiga kali seminggu tidak disarankan untuk pasien yang terinfeksi HIV dengan jumlah CD4+ kurang dari 100.

6. Simbol $(* *)$ berarti hanya digunakan untuk pasien HIV negatif dengan dahak negatif diselesaikan dalam terapi dua bulan dan pasien yang tidak memiliki rongga di dadanya. Untuk pasien yang memulai rejimen ini dan ditemukan budaya positif pada spesimen dua bulan, pengobatan diperpanjang menjadi tiga bulan tambahan.

\section{METODE}

Kerangka berpikir pada studi ini dapat dilihat pada Gambar 1:

Metodologi studi dimulai dari survei terhadap kebutuhan PT. PMI dan mencari parameter ketiga penyakit tersebut. Dari hasil survey selanjutnya dilakukan analisis masalah terhadap pelaksanaan disease management yaitu:

1. Adanya kesulitan dari pihak provider untuk mencari data karyawan seperti riwayat kesehatan karyawan, riwayat tempat kerja karyawan, riwayat tindakan dokter terdahulu terhadap karyawan, keanggotaan program Kesehatan Kerja (K2) karyawan.

2. Masalah berikutnya adalah sulit dalam memantau makanan dan aktivitas olahraga karyawan.

3. Sulit dalam pembuatan laporan kesehatan karyawan

4. Adanya peningkatan biaya pengobatan karena karyawan berobat ke dokter spesialis yang tidak sesuai. 


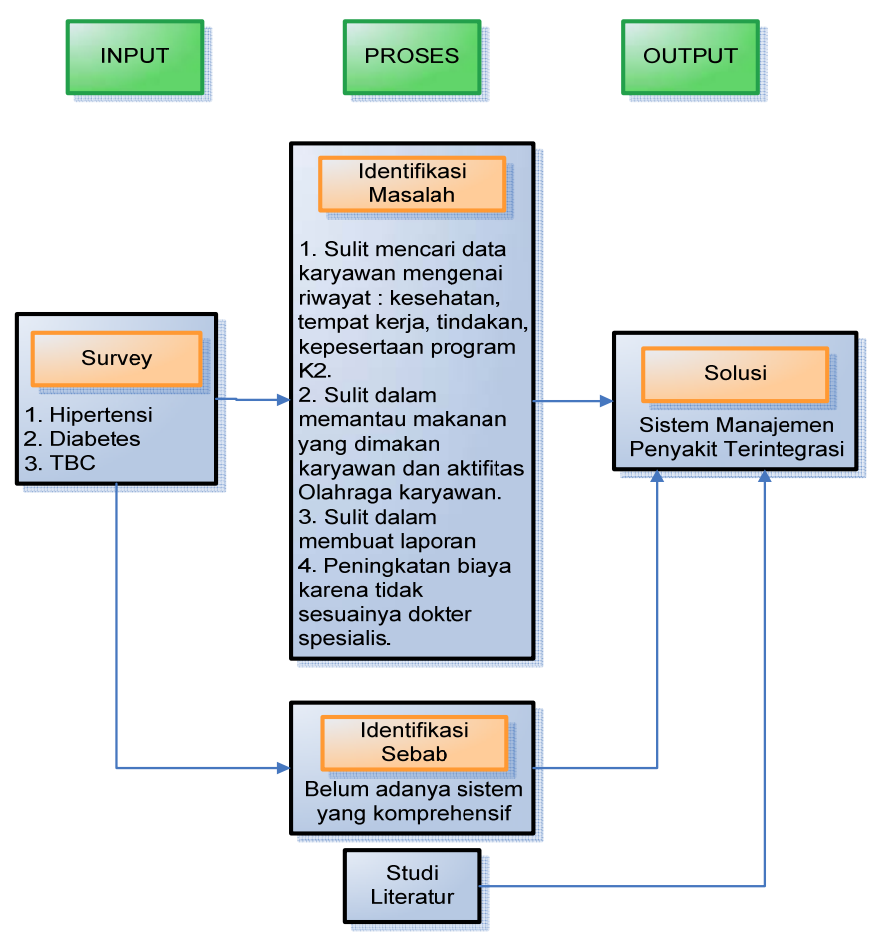

Gambar 1 Kerangka Pikir Penelitian

Studi literatur bertujuan untuk mencari pedoman dalam menghasilkan sistem disease management yang akan dirancang. Hasil dari studi berupa perancangan sistem manajemen penyakit yang terintegrasi dengan solusi berbasis web. Sistem yang dirancang dalam studi ini menggunakan pendekatan Chronic Care Model (CMM) untuk penanganan chronic disease management.

Disease management bertujuan untuk menjaga kesehatan karyawan dengan memantau makanan karyawan, aktifitas olahraga karyawan, mengikutsertakan karyawan pada program-program K2; konsultasi mingguan karyawan dengan dokter umum dan dokter K2.

Tujuannya adalah mengurangi risiko peningkatan sakit karyawan sehingga dapat mendukung kinerja karyawan. Dengan adanya sistem disease management yang terintegrasi, informasi dapat diperoleh dengan lebih mudah dan dapat memberi informasi dokter spesialis yang sesuai (satu provider dan ahli di bidangnya yang terkait dengan penyakit karyawan) kepada karyawan.

\section{HASIL DAN PEMBAHASAN}

Dalam studi ini, peran IT dalam mendukung Chronic Care Model (Wagner et al. 1999) difokuskan pada sistem informasi klinis berupa sistem register (registry system).

Registry System mengidentifikasi keterlambatan pasien, memberikan pedoman terkomputerisasi, menerapkan sistem manajemen perawatan, menghasilkan pengingat otomatis, menilai peningkatan kualitas, dan menghasilkan laporan khusus organisasi penyedia manajemen perawatan (East, Krishnamurthy, Freed, Nosovitski, 2003). Sistem registry mendukung perawatan penyakit kronis (Metzger, 2004). 
Registry menyediakan informasi penting untuk mengelola kondisi pasien secara individu. Fungsi dasar registry dijelaskan dibawah ini sesuai yang tersedia pada seluruh registry penyakit; fungsi lebih lanjut ditemukan di desain yang lebih kompleks.

Tabel 2 Fungsi Registry

\begin{tabular}{|c|c|c|}
\hline \multirow{2}{*}{$\begin{array}{l}\text { Elemen dari } \\
\text { manajemen } \\
\text { perawatan } \\
\text { kronis. }\end{array}$} & \multicolumn{2}{|c|}{ Fungsi Registry } \\
\hline & Dasar & Menengah \\
\hline $\begin{array}{l}\text { Memastikan } \\
\text { kegiatan rutin } \\
\text { untuk tindak } \\
\text { lanjut oleh tim } \\
\text { perawat. }\end{array}$ & $\begin{array}{l}\text { Lacak waktu yang diinginkan } \\
\text { untuk kunjungan berikutnya, tes, } \\
\text { atau hubungi berdasarkan } \\
\text { panduan perawatan } \\
\text { Memperbolehkan petugas klinik } \\
\text { untuk mencatat waktu tertentu } \\
\text { pasien untuk kunjungan } \\
\text { berikutnya atau intervensi. } \\
\text { Menyediakan daftar pasien } \\
\text { terurut berdasarkan status } \\
\text { keterlambatan (misalnya tidak } \\
\text { ada data HbA1C selama enam } \\
\text { bulan terakhir) atau status pasien } \\
\text { berdasarkan manajemen } \\
\text { pengawasan (misalnya HbA1C > } \\
\text { 8.0 atau tujuan pribadi) } \\
\text { Menyediakan daftar pasien yang } \\
\text { susah dihubungi atau } \\
\text { pengecualian untuk setiap dokter } \\
\text { atau tim perawat. }\end{array}$ & $\begin{array}{l}\text { - Menyediakan label } \\
\text { panggilan telepon atau surat } \\
\text { atau surat pengingat pasien } \\
\text { untuk ditindaklanjuti. } \\
\text { - Menampilkan tanggal } \\
\text { perjanjian berikutnya untuk } \\
\text { pasien yang berada dalam } \\
\text { daftar susah dihubungi atau } \\
\text { pengecualian. }\end{array}$ \\
\hline $\begin{array}{l}\text { Integrasi } \\
\text { panduan } \\
\text { berbasis bukti } \\
\text { kedalam } \\
\text { praktek klinik } \\
\text { harian. }\end{array}$ & $\begin{array}{l}\text { - Menggabungkan informasi } \\
\text { panduan manajemen perawatan } \\
\text { kedalam laporan dan } \\
\text { menampilkan anggota perawat. }\end{array}$ & $\begin{array}{l}\text { Masukkan petunjuk untuk } \\
\text { rekomendasi perubahan } \\
\text { dalam rencana perawatan } \\
\text { pasien menggunakan } \\
\text { algoritma berdasarkan } \\
\text { panduan dan informasi } \\
\text { khusus pasien. }\end{array}$ \\
\hline $\begin{array}{l}\text { Integrasi pakar } \\
\text { spesialis dan } \\
\text { dokter umum. }\end{array}$ & $\begin{array}{l}\text { - Menggabungkan panduan } \\
\text { perawatan untuk dokter umum } \\
\text { dengan informasi dari spesialis } \\
\text { terkait. }\end{array}$ & $\begin{array}{l}\text { - Menggabungkan informasi } \\
\text { kriteria keputusan untuk } \\
\text { pasien rujukan ke spesialis } \\
\text { dalam layar pasien dan } \\
\text { laporan untuk anggota } \\
\text { perawat. } \\
\text { Masukkan petunjuk untuk } \\
\text { rekomendasi rujukan untuk } \\
\text { pasien tertentu } \\
\text { menggunakan algoritma } \\
\text { berdasarkan panduan dan } \\
\text { informasi khusus pasien. }\end{array}$ \\
\hline $\begin{array}{l}\text { Memberikan } \\
\text { pengingat tepat } \\
\text { waktu untuk } \\
\text { penyedia } \\
\text { perawatan } \\
\text { kesehatan dan } \\
\text { pasien }\end{array}$ & $\begin{array}{l}\text { - Lacak waktu yang diinginkan } \\
\text { untuk kunjungan berikutnya, } \\
\text { tes, atau hubungi berdasarkan } \\
\text { panduan perawatan. } \\
\text { - Memperbolehkan petugas klinik } \\
\text { untuk mencatat waktu tertentu } \\
\text { pasien untuk kunjungan }\end{array}$ & $\begin{array}{l}\text { - Kirim notifikasi email } \\
\text { untuk dokter atau tim } \\
\text { perawat ketika registry } \\
\text { pasien berada pada bagian } \\
\text { gawat darurat. }\end{array}$ \\
\hline
\end{tabular}




\begin{tabular}{|c|c|c|}
\hline $\begin{array}{l}\text { Identifikasi } \\
\text { subpopulasi } \\
\text { yang sesuai } \\
\text { untuk } \\
\text { perawatan }\end{array}$ & $\begin{array}{l}\text { berikutnya atau intervensi. } \\
\text { Berikan informasi mengenai } \\
\text { tanggal kunjungan dan } \\
\text { intervensi lainnya dalam } \\
\text { laporan pasien dan layar. } \\
\text { - } \quad \text { Lacak informasi untuk } \\
\text { mengidentifikasi subpopulasi } \\
\text { pasien dengan kondisi kronis. } \\
\text { Kelola daftar pasien yang aktif } \\
\text { maupun bertunangan untuk } \\
\text { setiap PCP dan tim perawat. }\end{array}$ & 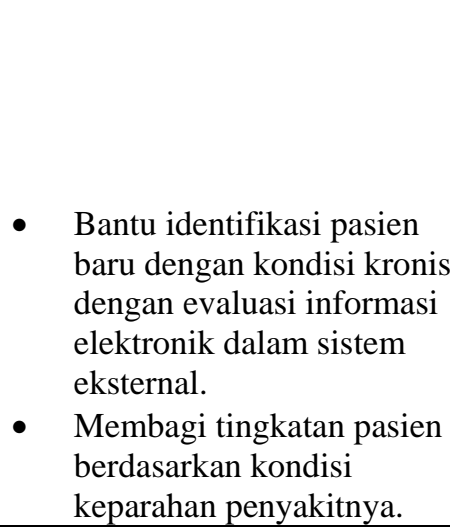 \\
\hline
\end{tabular}

Sistem informasi klinis yang dirancang berupa sistem register (Gambar 2 dan 3) yang terdiri atas Electronic Health Record, Alert Management System, dan Reporting System. Alert Management System bertujuan mendukung manajemen diri pasien. Edukasi pasien sebagai langkah pemeliharaan (treatment) pasien dapat didukung dalam hal informasi penjadwalan dan dengan adanya electronic guideline untuk pasien. Sistem yang dirancang adalah sistem berbasis web.

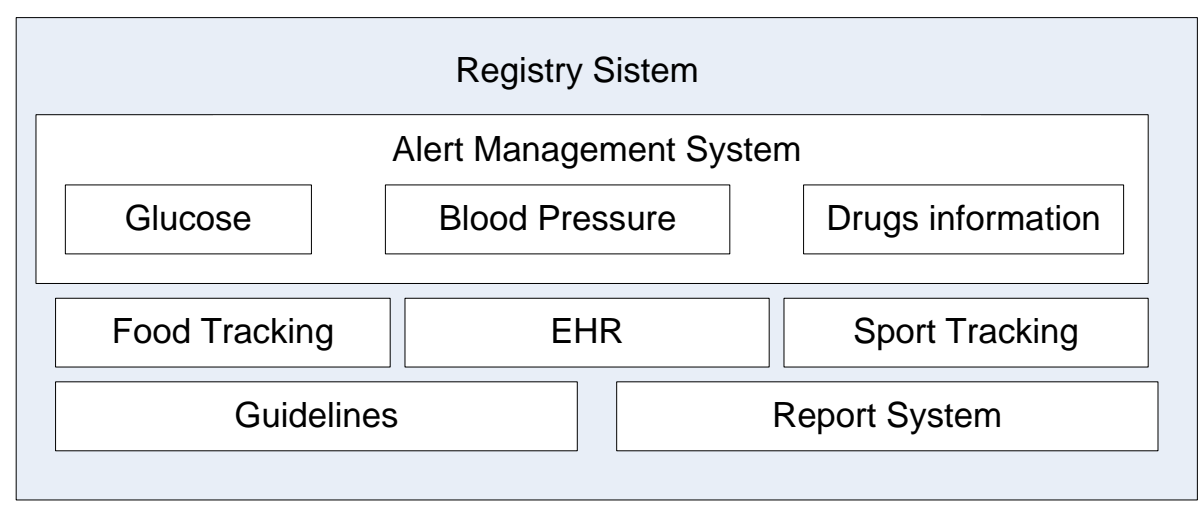

Gambar 2 Registry System

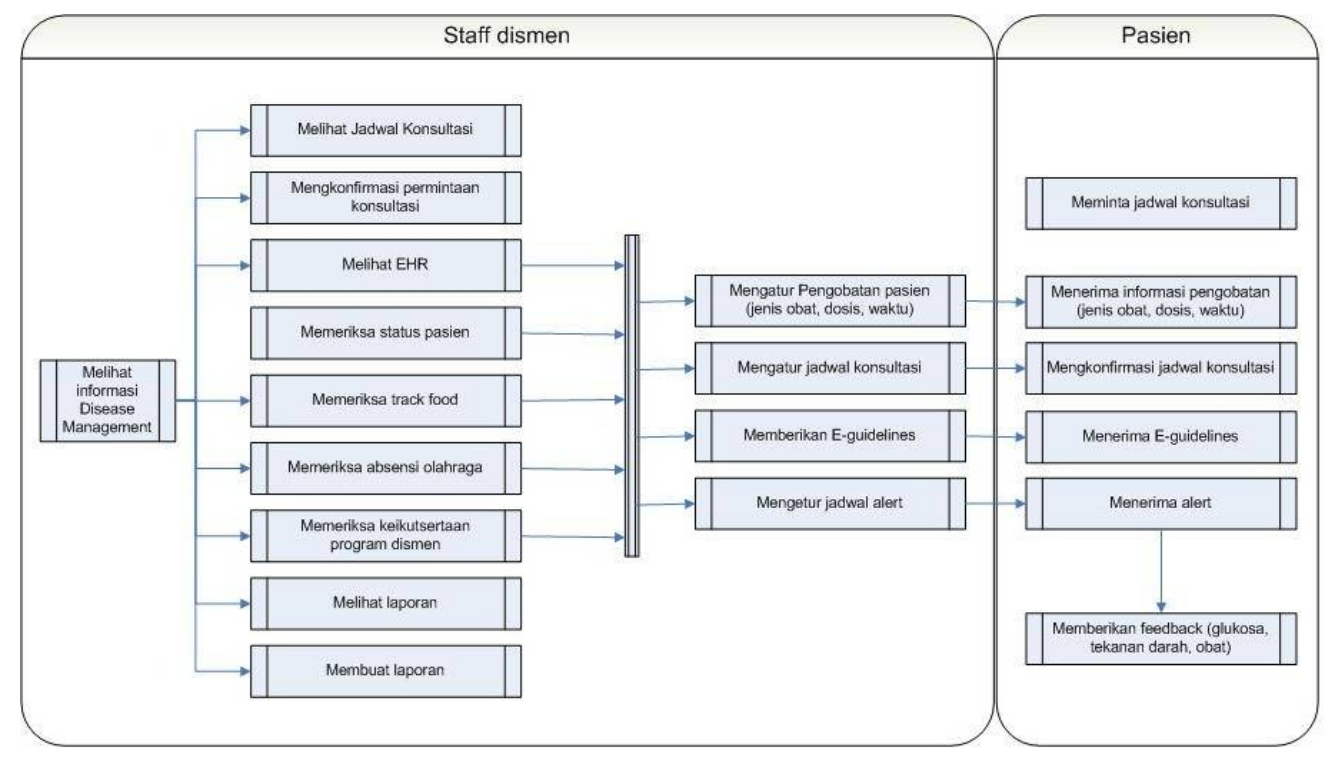

Gambar 3 Alur Proses Sistem Registri yang Dirancang 
Alert Management System diadakan untuk membantu mengetahui keadaan pasien (kadar gula dalam darah pasien untuk penderita diabetes, tekanan darah pasien untuk penderita hipertensi, dan obat dengan dosis tertentu yang telah dikonsumsi oleh pasien dalam waktu tertentu oleh penderita TBC).

Paganelli dan Giuli (2007) menggambarkan kerangka aplikasi home-based services untuk pemantauan dan penanganan kondisi pasien berpenyakit kronis dengan menyediakan informasi status kesehatan pasien serta adanya mekanisme untuk alarm. Aplikasi ini mendukung adanya layanan darurat, informasi tentang kegiatan harian pasien (nutrisi, komunikasi, asumsi obat, pemantauan tandatanda vital), peningkatan kualitas hidup dan mendukung perawatan diri (pendidikan, sosialisasi).

Berdasarkan Dickson, Kwok, dkk (2004) Alert Management System mempunyai dua bagian yaitu alert creating module (Incoming Alert Monitor) dan execution module (Outgoing Alert Monitor). Dalam studi ini, Alert Management System yang dirancang ditunjukkan pada Gambar 4.

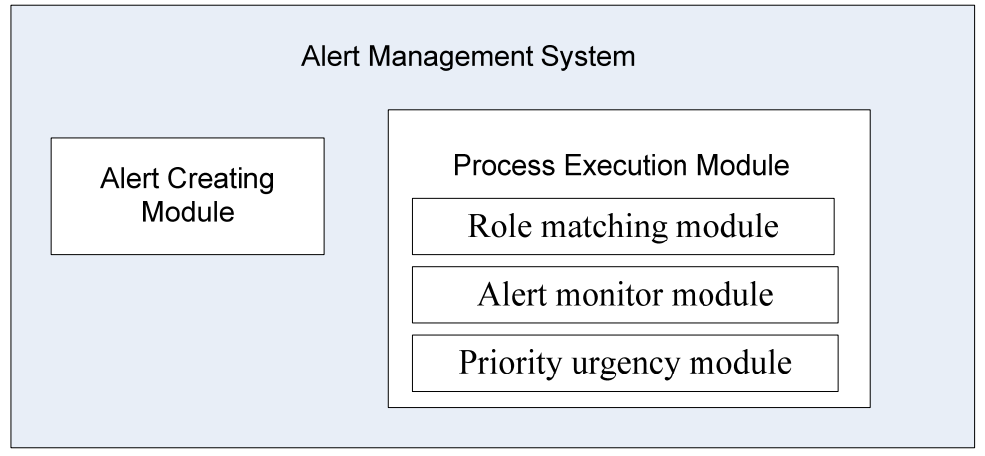

Gambar 4 Alert Management System

Dalam Alert Management System tingkat urgensi dibagi menjadi tiga level seperti pada Tabel 3 berikut:

Tabel 3 Tingkat Urgensi Alert Dan Aksi Yang Dilakukan

\begin{tabular}{ll}
\hline \multicolumn{1}{c}{ Urgensi } & \multicolumn{1}{c}{ Aksi } \\
\hline Normal & Email \\
Urgen & SMS ke pasien \\
Kritis & SMS ke staff dismen \\
\hline
\end{tabular}

Dari tabel 3 tersebut, fungsi urgensi $U(t)$ didefinisikan sebagai berikut :

$$
\mathrm{U}(\mathrm{t})=\left\{\begin{array}{l}
\text { Normal, } \mathrm{t}=\mathrm{T} \\
\text { Urgen, } \mathrm{T}<\mathrm{t}<\mathrm{T}+\mathrm{dt} 1 \\
\text { Kritis, } \mathrm{T}+\mathrm{dt} 1<\mathrm{t}<\mathrm{T}+\mathrm{dt} 1+\mathrm{dt} 2
\end{array}\right.
$$

dimana :

$\mathrm{T}=$ deadline normal (default)

$\mathrm{dt} 1=$ deadline urgen

dt2 = deadline kritis

Jika tidak ada respons dari pasien setelah deadline normal T maka tingkat urgensi akan naik ke dari level normal ke urgen dan kembali mengirimkan alert. Selanjutnya ketika tidak ada respon setelah 
deadline urgen maka level urgensi akan meningkat ke level kritis dan kembali mengirimkan alert. Skenario yang diberikan untuk penentuan tingkat urgensi sistem:

\section{Sistem memberikan alert kepada pasien untuk melakukan pengecekan tekanan darah.}

Sistem akan memberikan alert yaitu email untuk mengingatkan pasien melakukan pengecekan tekanan darah sesuai jadwal yang disediakan untuk pasien. Jika pasien tidak memberikan respon berupa nilai tekanan darah yang diminta maka level urgensi meningkat dari normal menjadi urgensi diikuti dengan pengiriman alert berupa SMS ke handphone pasien. Jika pasien tidak memberikan respon maka level urgensi meningkat menjadi kritis dan tindakan yang dilakukan sistem adalah memberikan alert berupa SMS ke staff DisMen. Staff DisMen kemudian akan menelepon pasien untuk melakukan pengecekan tekanan darahnya. Prosesnya terdapat pada Gambar 5.

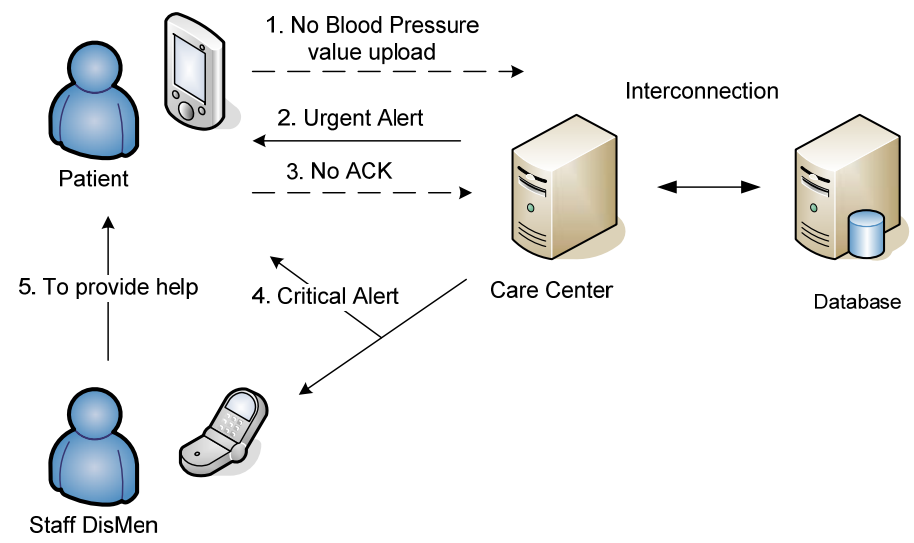

Gambar 5 Prosedur Pesan Untuk Pasien Melakukan Pengecekan Tekanan Darah

\section{Sistem memberikan alert kepada pasien untuk melakukan kontrol ke klinik.}

Sistem akan mengirimkan alert kepada pasien untuk melakukan kontrol sesuai jadwal yang telah ditentukan oleh dokter DisMen. Pasien dapat melakukan registry online dan mengetahui informasi antrian. Ketika nama pasien dipanggil untuk melakukan konsultasi maka pasien dan dokter yang akan menanganinya akan memperoleh notifikasi. Dokter akan memperoleh rekam medis pasien. Prosedur terlihat pada Gambar 6.

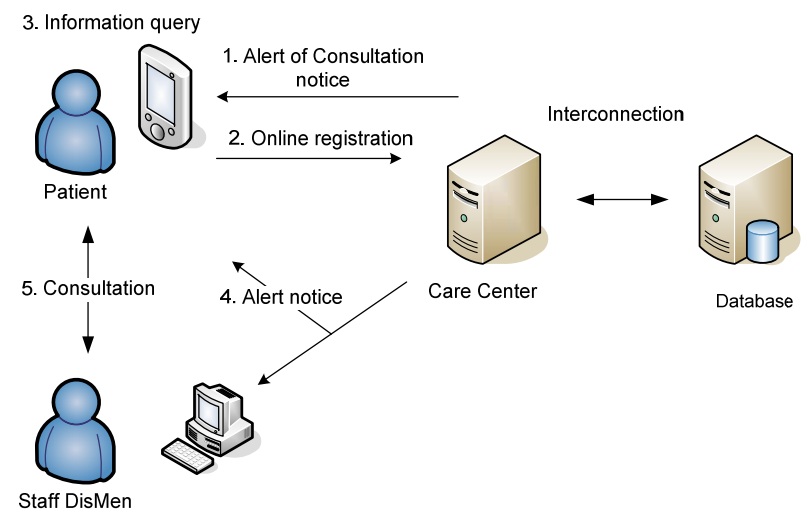

Gambar 6 Prosedur Pesan Untuk Pasien Melakukan Kontrol Ke Klinik 
Nilai tekanan darah yang diterima oleh sistem kemudian disimpan dan diklasifikasikan. Seperti pada flowchart (Gambar 7) di bawah, status pasien berdasarkan systolic dan diastolic terbagi atas empat status yaitu normal ketika sistol kurang dari $120 \mathrm{mmHg}$ dan diastol kurang dari $80 \mathrm{mmHg}$, Prehipertensi ketika sistol berada di antara 120 - 139 mmHg atau diastol 80 - 89 mmHg, Hipertensi tahap 1 ketika sistol berada di antara 140 - 159 mmHg atau diastol 90 - 99 mmHg, dan Hipertensi tahap 2 ketika sistol diatas $160 \mathrm{mmHg}$ atau diastol diatas $100 \mathrm{mmHg}$. Status ini akan disimpan dalam database sehingga dapat dipantau oleh pasien maupun oleh pihak staf dismen.

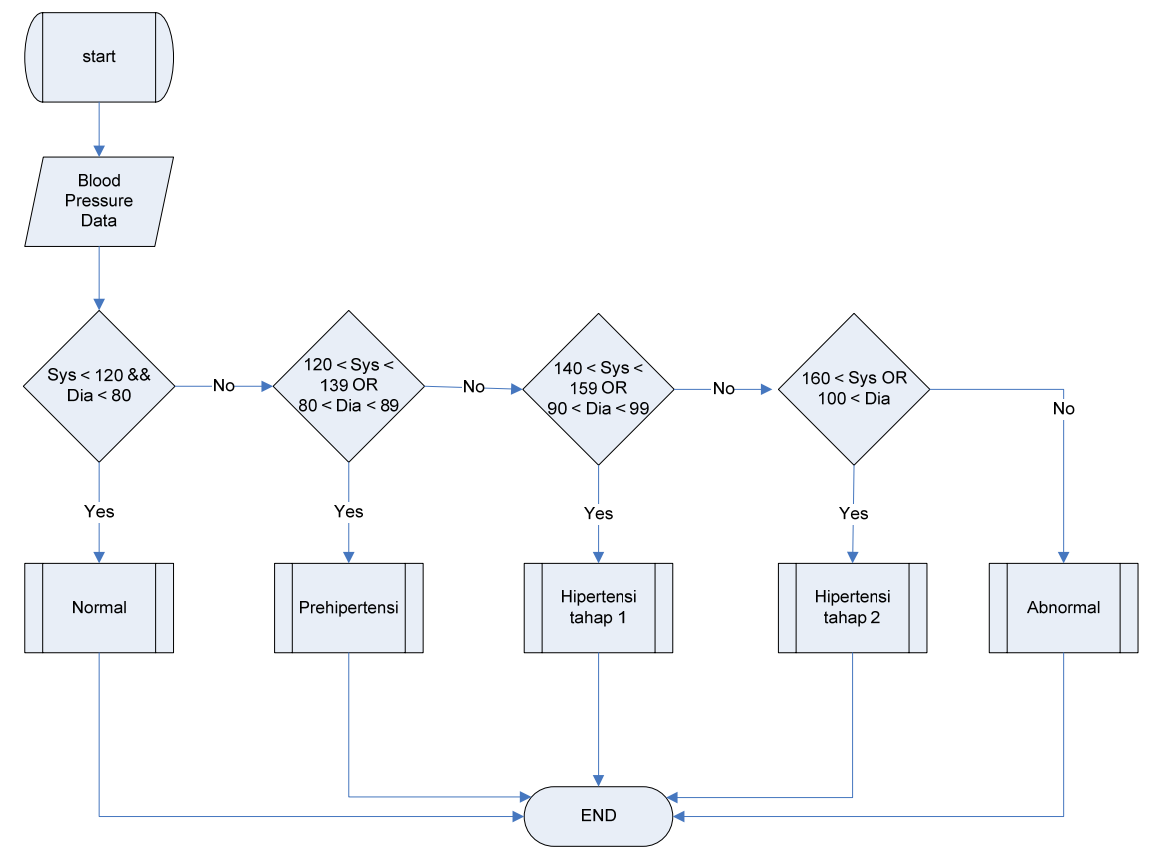

Gambar 7 Flowchart Penentuan Status Tekanan Darah

Keterangan :

Sys : Systolic

Dia : Diastolic

Satuan dalam mmHg

Data tekanan darah ini disimpan sehingga dapat dilihat dan dipantau oleh staf dismen (lihat Gambar 8, 9 dan 10). Data lain yang juga dapat ditampilkan oleh sistem adalah data absensi olahraga, data makanan, EHR, dan program dismen apa saja yang telah dan sedang diikuti oleh pasien.

\begin{tabular}{|c|c|c|c|c|c|c|c|c|}
\hline & \multicolumn{2}{|c|}{ Home } & \multicolumn{2}{|c|}{ Profile } & Report & \multicolumn{2}{|c|}{ Help } & \\
\hline \multicolumn{9}{|l|}{ Consultation Schedule } \\
\hline $\begin{array}{l}\text { Disease Management } \\
\text { Diabetes }\end{array}$ & NIK & Name & $\begin{array}{l}\text { Absensi } \\
\text { olahraga }\end{array}$ & $\begin{array}{l}\text { food } \\
\text { tracking }\end{array}$ & \multicolumn{2}{|c|}{ status tracking } & EHR & $\begin{array}{l}\text { Program } \\
\text { dismen }\end{array}$ \\
\hline Hypertension & $x x x x x$ & $x x x x x$ & check & check & check & & check & check \\
\hline TBC & & & & & & & & \\
\hline
\end{tabular}

Gambar 8 User Interface Melihat Data Pasien Hipertensi 


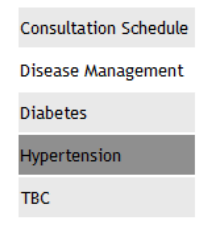

Hypertension

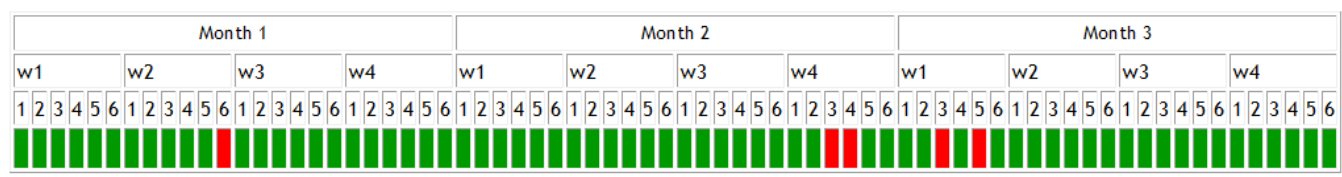

Gambar 9 User Interface Melihat Data Status Tekanan Darah Pasien

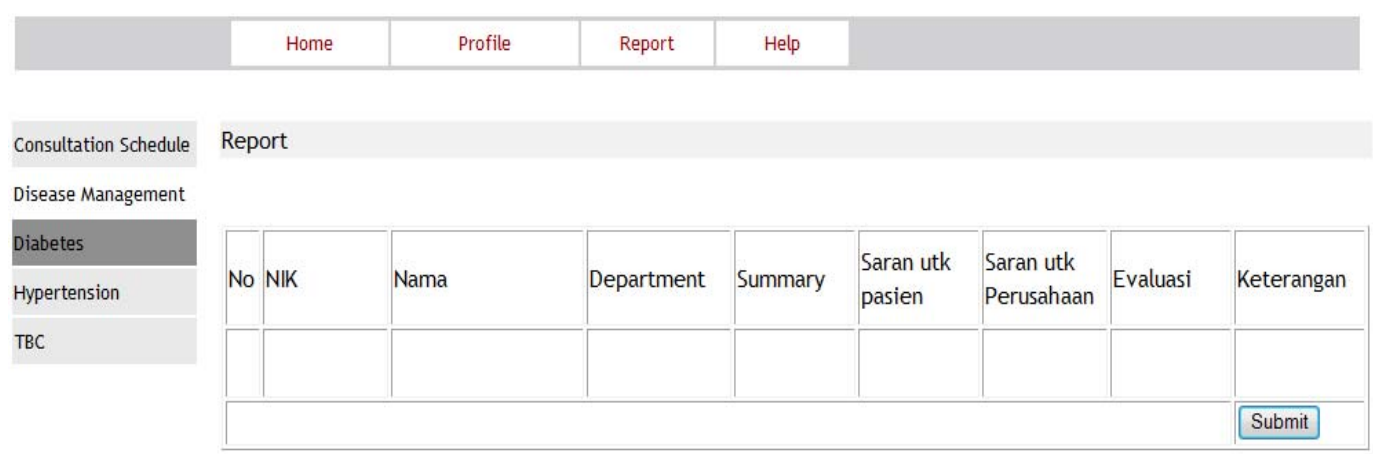

Gambar 10 User Interface Membuat Laporan

\section{SIMPULAN}

Karyawan yang sakit tentu akan memerlukan biaya pengobatan terutama bila menderita penyakit kronis yang memerlukan biaya pengobatan untuk jangka waktu tertentu. Salah satu strategi untuk menekan biaya pengobatan ini adalah dengan merancang program disease management.

PT. PMI telah memiliki program disease management (dismen) sebelumnya, namun belum menggunakan teknologi informasi dalam penerapannya. Hal ini menimbulkan kesulitan dalam penerapannya yaitu antara lain: (1) Adanya kesulitan dari pihak provider untuk mencari data karyawan seperti riwayat kesehatan karyawan, riwayat tempat kerja karyawan, riwayat tindakan dokter terdahulu terhadap karyawan, kepesertaan program Kesehatan Kerja (K2) karyawan; (2) Masalah berikutnya adalah sulit dalam memantau makanan karyawan dan aktivitas olahraga karyawan; (3) Sulit dalam pembuatan laporan kesehatan karyawan; dan (4) Adanya peningkatan biaya pengobatan karena karyawan berobat ke dokter spesialis yang tidak sesuai.

Program dismen yang paling umum di PT. PMI adalah loket rendah garam untuk penderita hipertensi dan olahraga. Staff dismen dapat mengetahui karyawan mana yang mengikuti program dismen pada saat konsultasi. Jika pada saat konsultasi (dalam kasus ini penderita hipertensi) kondisi pasien lebih buruk dari sebelumnya maka akan dicek dari laporan di loket olahraga dan absensi olahraga.

Setelah memiliki solusi teknologi informasi berbasis web, maka staff dismen (disease management) PT. PMI akan dapat melihat jadwal konsultasi, mengkonfirmasi permintaan konsultasi, melihat EHR, memeriksa status pasien, memeriksa track food, memeriksa absensi olahraga, memeriksa keikutsertaan program dismen, melihat laporan, dan membuat laporan. Kemudian disediakan fungsi tambahan untuk mengatur pengobatan pasien, mengatur jadwal konsultasi, memberikan e-guidelines, dan mengatur jadwal alert. Hal ini diperlukan untuk mempercepat kinerja kerja staff dismen ketika melakukan konsultasi terhadap peserta dismen. Sebelum diterapkan solusi 
disease management, staff dismen menghabiskan waktu dengan melakukan tanya jawab terhadap karyawan mengenai data mereka.

Pasien akan diingatkan dengan adanya alert yang berupa email untuk memasukkan hasil pengukuran terbaru mereka. Dan mereka tidak perlu menunggu selama sebulan untuk mengetahui hasil pengukuran mereka di klinik. Sehingga mereka juga semakin perduli dengan kesehatan mereka, karena mereka akan memasukkan hasil pengukuran mereka secara rutin. Pasien dan petugas dismen juga dapat melihat catatan pengukuran yang terdahulu pada halaman web dismen PT. PMI.

Studi ini tidak membahas hasil evaluasi disease management yang telah dilakukan pada PT. PMI. Tetapi hanya merancang solusi teknologi informasi pada disease management berbasis web yang disesuaikan dengan kebutuhan PT. PMI. Studi ini difokuskan pada tiga penyakit yaitu diabetes, hipertensi, dan TBC. Studi ini tidak membahas mengenai indikator penyakit lainnya seperti yang terjadi pada penyakit komplikasi. Studi ini juga tidak membahas pemberian alert pada program dismen yang lain seperti olahraga dan loket rendah garam. Alert yang diberikan bertujuan untuk mengingatkan pasien tentang kondisi terkininya.

Studi ini bisa dikembangkan lagi dengan menambahkan penyakit lain untuk diikutsertakan dalam sistem disease management. Atau bisa dapat menambahkan alert untuk mengikuti kegiatan olahraga. Sebaiknya pasien dilengkapi dengan alat pembaca kadar gula darah atau tekanan darah otomatis sehingga pasien tidak perlu menginput data mereka sendiri. Pada studi sejenis ada yang telah merancang sistem yang dapat membaca hasil pengukuran pasien dan mengirimkannya ke layanan kesehatan. Studi ini juga bisa dilakukan sebagai bahan evaluasi untuk melihat sejauh mana dismen PT. PMI dapat menekan biaya pengobatan karyawannya.

\section{DAFTAR PUSTAKA}

Beauliau, N. D., Cutler, D. M., Ho, K. E., Horrigan, D., \& Isham, G. (2003). The Business Case for Diabetes Disease Management at Two Managed Care Organizations: A Case Study of Healthpartners and Independent Health Association. Retrieved from http://www.commonwealthfund.org

Beich, J., Scanlon, D. P., Ulbrecht, J., Ford, E. W., \& Ibrahim, I. A. (2006). The Role of Disease Management in Pay - for - Performance Programs for Improving the Care of Chronically Ill Patients. Med Care Res. 63(96S). doi: 10. 1177 / 1077558705283641.

Bodenheimer, T., Wagner, E. H., Grumbach, K. (2002). Improving Primary Care for Patients with Chronic Illness. JAMA. 288(14), 1775 - 1779.

Bowles, K., Holland, D., \& Horowitz, D. (2009). A Comparison of In-person Home Care, Home Care with Telephone Contact and Home Care with Telemonitoring for Disease Management. Journal of Telemedice \& Telecare, 15(7), 344-350. doi:10.1258/jtt.2009.090118.

Bowles, K., Pham, J., \& O’Connor, M. (2010). Information Deficits in Home Care: A Barrier to Evidence-Based Disease Management. Home Health Care Management \& Practice, 22(4), 278-285. doi:10.1177/1084822309353145.

Centers for Disease Control and Prevention. (2010). Tuberculosis. Retrieved from http://www.cdc.gov/tb 
Dickson, K. W., et. al. (2004). Alert-driven E-service Management. Proceedings of the 37 th Hawaii international Conference on System Sciences.

East, J., Krishnamurthy,. P., Freed, B., Nosovitski, G. (2003). Impact of a diabetes electronic management system on patient care in a community clinic. American Journal of Medical Quality, 18(4), 150-154.

Frei, A., Chmiel, C., Schläpfer, H., Birnbaum, B., Held, U., Steurer, J., \& Rosemann, T. (2010). The Chronic CARe for Diabetes Study (CARAT): A Cluster Randomized Controlled Trial. Cardiovascular Diabetology. 9(23), 1-11.

Langford, Sawyer, Gioimo, Brownson, \& O’Toole. (2007). Patient-Centered Goal Setting as a Tool to Improve Diabetes Self-Management. The Diabetes EDUCATOR. 33(6). doi:10.1177/0145721707304475.

Metzger, J. (2004). Using computerized registries in Chronic Disease care. First Consulting Group. Prepared for the California HealthCare Foundation. Diunduh dari: http://www.chcf.org/topics/view.cfm?itemID=21718\&dir=chronicdisease

Nutting, P. A., Dickinson, W. P., Dickinson, L. M., Nelson, C. C., King, D. K., Crabtree, B. F., \& Glasgow, R.E. (2007). Use of Chronic Care Model Elements is Associated With HigherQuality Care for Diabetes. Annals of Family Medicine, 5(1), 14-20.

Strickland, P. A. O., Hudson, S. V., Piasecki, A., Hahn, K., Cohen, D., Orzano, A. J., Parchman, M. L., \& Crabtree, B. F. (2010). Features of the Chronic Care Model associated with behavioral counseling and diabetes care in community primary care. J Am Board Fam Med. 23(3), 295305. doi:10.3122/jabfm.2010.03.090141.

US National Library of Medicine [NLM]. (2010). Hypertension. Retrieved from http://www.nlm.nih.gov/medlineplus/ency/article/000468.htm

Wagner, E. H., Davis, C., Schaefer, J., Von Korff, M., \& Austin, B. (1999). A Survey of Leading Chronic Disease Management Programs: Are They Consistent with The Literature ? Manag Care Q. 7(3), 56-66.

Zai, A. H., Grant, R.W., Estey, G., Lester, W. T., Andrews, C. T., Yee, R., Mort, E., \& Chueh, H. C. (2008). Lessons from Implementing a Combined Workflow - Informatics System for Diabetes Management. Journal of the American Medical Informatics Association. 15(4), 524-533. doi:10.1197/jamia.M2598. 